\title{
THE INTERNATIONALIZATION PROCESS OF THE LARGEST BALTIC CORPORATIONS
}

\author{
Kari Liuhto, Jari Jumpponen \\ The Research Group for Russian and East European Business, Lappeenranta University of Technology, \\ PO. Box 20, FIN-53851 Lappeenranta, Finland
}

Received: 18 November, 2002

\begin{abstract}
A relatively high percentage of Baltic corporations have already started their operations abroad, over $40 \%$ of the companies studied. It is surprising that the approaching EU membership docs not seem to be the driving force of the Baltic corporations' internationalization, though the EU is clearly the major export destination. The empirical evidence shows that the operations of the Baltic companies in foreign markets, have concentrated on the ex-CMEA countries, especially on the former USSR. The empirical data indicates that most of the operations abroad are related to marketing, such as the foundation of their own representative office or their own sales unit in a foreign market.
\end{abstract}

Keywords: Baltic States, international business, internationalization, REM-model, Estonia, Latvia, Lithuania

\section{Introduction}

The Baltic States are very small. Their population, even combined, is only 7.5 million, which is less than the population of Austria. The small size of the Baltic economies becomes emphasized, when their GDP is analyzed. In 2000, the GDP of all the three Baltic States, measured at purchasing power parity (PPP) was some USD 60 billion. Even the GDP of Ireland (USD 82 billion), which is among the least wealthy of EU members, is higher than the total Baltic GDP. Finland's GDP was some double that of the whole Baltics [1].

The small size of their economy obviously pushes Baltic companies abroad. Clear evidence of Baltic firms' internationalization at the macrocconomic level is the high exports-GDP ratio. In 2000, the exports of goods and services were some 45-96\% compared to the GDP, depending on the Baltic State in question [2]; [3]; [4]). ${ }^{1}$

In 1990, the overwhelming majority of the Baltic

\footnotetext{
${ }^{1}$ According to the Economist Intelligence Unit, the exports/GDP ratio was in Estonia 96.5\%, while in Latvia it was $45.8 \%$, and in Lithuania 45.5\%, respectively (EIU 2001a; 2001b; 2001c).
}

States' foreign trade was directed to other socialist countries. Then, the CMEA covered over $90 \%$ of the Baltic States' exports [5]. Ten years later, the direction of the foreign trade has reversed almost completely. In 2000, the EU was the main trade partner of the Baltic States. Exports to the EU covered some $65 \%$ of the Estonian exports. The respective share in Latvia was close to that of Estonia, but in Lithuania the EU share was remarkably lower, less than $50 \%$. Also the imports from the EU are significant. The EU represented roughly $45-75 \%$ of the Baltic countries' imports, Estonia being the most dependent and Lithuania the least dependent on the imports from the EU.

Whilst the EU's importance in Baltic foreign trade has grown rapidly, the dependence on Russian trade has declined. In 2000, Russia covered only $2-7 \%$ of the Baltic exports, Estonia being the least Russia-oriented and Lithuania the most Russia-oriented. Russia's proportion of Baltic imports is considerably higher than that of their exports. In Lithuania, the dependence on imports from Russia is by far the highest, almost $30 \%$. In Estonia and Latvia, Russia formed just some 10\% of the total imports [6]; [7]; [8]. 
Besides foreign trade flows, the foreign direct investment (FDI) inflows verify that the Baltic countries are open economies. In 1999, the FDI-inflow represented $4-5 \%$ of the Baltic GDP. The Baltic States have attracted much more FDI per capita than other ex-Soviet republics. The cumulative FDI inflow per capita during 1989-1999 in the Baltic States was over USD 750 , whilst in other formerly Soviet republics it was less than USD 150 [9].

Finland and Sweden are the most important investor countries in Estonia, where they together formed some $70 \%$ of the Estonian FDI stock in 2000. Denmark, in turn, is the biggest investor both in Latvia and Lithuania. The Baltic States covered only a modest part of the FDI in another Baltic State. Only Estonia managed to climb among the top 10 investor countries with approximately a 6\% FDI stake both in Latvia and Lithuania [10]; [11].

The FDI has supported the recovery of the Baltic States from the transition slump and has enhanced the improvement of enterprise competitiveness both directly (foreign owner impact) and indirectly (via competition or copying competitiveness). Along with the development of their competitiveness, the Baltic companies have not only intensified their export activities, but they have begun to invest outside their home market.
As the authors were not able to find any comprehensive report on the outward investments from the Baltic States, it is impossible to state how much the Baltic companies have already invested abroad. Even without any investigation concerning outward investments from the Baltic States, it can be rather safely stated that investment inflows to the Baltic States are still larger than the investment outflows from the Baltic States. Although the investment outflow is insignificant when compared to the investment inflow, some single Baltic companies have already shifted a great share of their assets abroad. In fact, a Latvian company was ranked the second most transnational company among the Central and East European firms in 1999 (see Table 1).

Though only one Baltic company reached the top 25 list, the importance of the monitoring the Baltic companies' expansion abroad becomes emphasised, due to the accelerating globalization of business. The Baltic corporations cannot simply afford to underestimate the pressures created by globalization.

\section{The REM Internationalization Model}

The REM model is comprised of three main components: (1) the R-factor - reason to internationalize; (2) the E-factor - environmental selection; and (3) the Mfactor - modal choice.

Table 1. Top 25 Non-Financial Transnational Corporation based in Central Eastern Europe (ranked by foreign assets, 1999). Source: [12]

\begin{tabular}{|c|c|c|c|c|c|c|c|c|c|}
\hline \multirow[t]{2}{*}{ CORPORATION } & \multirow[t]{2}{*}{ COUNTRY } & \multirow[t]{2}{*}{ INDUSTRY } & \multicolumn{2}{|c|}{$\begin{array}{l}\text { ASSETS } \\
\quad(\text { USD mn) }\end{array}$} & \multicolumn{2}{|c|}{$\begin{array}{l}\text { SALES } \\
\quad(\text { USD mn) }\end{array}$} & \multicolumn{2}{|c|}{$\begin{array}{l}\text { EMPLOYMENT } \\
\text { (Empl. number) }\end{array}$} & \multirow[t]{2}{*}{$\begin{array}{l}\text { TNI ' } \\
(\%)\end{array}$} \\
\hline & & & FOREIGN & TOTAL & FOREIGN & TOTAL & FOREIGN & TOTAL & \\
\hline 1. Lukoil Oil Co. & Russia & Petroleum \& gas & 3236.0 & 8422.0 & 4642.0 & 10903.0 & 10000 & 120000 & 30 \\
\hline 2. Latvian Shipping Company & Latvia & Transportation & 459.0 & 470,0 & 191.0 & 191.0 & 1124 & 1748 & 87 \\
\hline 3. Hrvatska Elektroprivreda & Croatia & Energy & 296.0 & 2524.0 & 10.0 & 780.0 & & 15877 & 4 \\
\hline 4 Podravka Group & Croatia & Food \& pharmac. & 285.9 & 477.1 & 119.4 & 390.2 & 501 & 6898 & 33 \\
\hline 5. Primorsk Shipping Co. & Russia & Transportation & 256.4 & 444.1 & 85.3 & 116.5 & 1308 & 2777 & 59 \\
\hline 6. Gorenje Group & Slovenia & Domestic applian. & 236.3 & 618.1 & 593.3 & 1120.6 & 590 & 6691 & 33 \\
\hline 7. Far Eastern Shipping Co. & Russia & Transportation & 236.0 & 5850 & 134.0 & 183.0 & 263 & 8873 & 39 \\
\hline 8. Pliva Group & Croatia & Pharmaceuticals & 181.8 & 915.9 & 3847 & 587.6 & 2645 & 7857 & 40 \\
\hline 9. TVK Ltd * & Hungary & Chemicals & 175.4 & 553.2 & 248.9 & 394.3 & 927 & 5225 & 38 \\
\hline 10. Motokov & Czech Rep. & Trade & 1636 & 262.5 & 260.2 & 349.1 & 576 & 1000 & 65 \\
\hline 11. Skoda Group PIzen & Czech Rep & Diversified & 139.1 & 973.4 & 150.7 & 1244.5 & 1073 & 19830 & 11 \\
\hline 12. Atlanska Plovidba & Croatia & Transportation & 138.0 & 154.0 & 46.0 & 46.0 & & 509 & 63 \\
\hline 13 MOL Hungarian Oil \& Gas & Hungary & Petroleum \& gas & 126.3 & 3131.0 & 582.4 & 3129.6 & 833 & 20684 & 9 \\
\hline 14. Krka & Slovenia & Pharmaceuticals & 120.7 & 447.0 & 209.0 & 283.0 & 429 & 3218 & 38 \\
\hline 15. Adria Airways & Slovenia & Transportation & 116.3 & 129.2 & 103.4 & 104.6 & 19 & 597 & 64 \\
\hline $\begin{array}{l}\text { 16. Petrol } \\
\text { 17. Slovnaft * }\end{array}$ & $\begin{array}{l}\text { Slovenia } \\
\text { Slovakia }\end{array}$ & $\begin{array}{l}\text { Petroleum \& gas } \\
\text { Petroleum \& gas }\end{array}$ & $\begin{array}{l}90.4 \\
82.8\end{array}$ & $\begin{array}{r}574.9 \\
1367.1\end{array}$ & $\begin{array}{l}105.7 \\
627.5\end{array}$ & $\begin{array}{r}924.4 \\
1035.7\end{array}$ & $\begin{array}{r}75 \\
119\end{array}$ & $\begin{array}{l}2356 \\
7540\end{array}$ & $\begin{array}{l}10 \\
23\end{array}$ \\
\hline 18. Zalakeramia & Hungary & Clay product & 69.0 & 125.0 & 39.0 & 64.0 & 2022 & 3066 & 61 \\
\hline 19. Matador & Slovakia & Rubber \& plastics & 51.9 & 305.0 & 34.0 & 203.4 & 5 & 3878 & 11 \\
\hline 20 Malev Hungarian Airlines & Hungary & Transportation & 43.3 & 206.3 & 274.1 & 367.5 & 49 & 3162 & 32 \\
\hline 21 KGHM Polska Miedz & Poland & Mining & 34.0 & 1266.0 & 265.0 & 1155.0 & 25 & 28300 & 9 \\
\hline 22. Croatia Airlines & Croatia & Transportation & 29.9 & 288.6 & 60.2 & 77.9 & 39 & 842 & 31 \\
\hline 23 Elektrim & Poland & Diversified & 21.0 & 1228.0 & 42.0 & 874.0 & 62 & 26475 & 2 \\
\hline 24. Petrom National Oil Co. & Romania & Petroleum \& gas & 19.0 & 2970.0 & 211.0 & 2041.0 & 67 & 82054 & 4 \\
\hline 25 Intereuropa & Slovenia & Trade & 16.0 & 168.0 & 17.0 & 136.0 & 511 & 2103 & 15 \\
\hline
\end{tabular}

${ }^{1}$ The TNI, the transnational try index, is calculated as the average of three ratios: foreign assets to total assets, foreign sales to total sales and foreign employment to total employment (see EBRD, 2000). * TVK and Slovnaft have been taken over by MOL. 
The R-factor: a reason for internationalization creates the foundation of the REM model, as it answers why a firm decides to internationalize in the first place. According to [13], some companies internationalize due to external motives, for instance, their rivals and customers' operations have become global. There is also evidence that internal factors, such as a goal to increase the firm's profitability, push enterprises to begin their internationalization [14].

The E-factor: the environment selection stands for the choice of business environment(s). As national borders arc disappearing out of the way of various free trade areas or economic unions, the environment seems to be a more appropriate term than that of country or location [15].

There are a multitude of factors, which influence environment selection. [16] describes some variables influencing the environment selection decision and how the issues behind the decision-making have changed during the 1970s and the 1990s (see Table 2).

The M-factor: the modal choice answers the question of how a firm implements its internationalization. Since neither a universally superior mode nor environment exists, the modal choice depends on the environment selection, and vice versa. The selection be- tween the different modes is influenced by many issues, such as the control requirement, commitment, costs, the value creative potential and the complexity involved, experience, the capabilities and resources possessed,.partner-related risks and national/cultural preferences, the knowledge-sharing policy, and most of all the firm's overall strategy (e.g. [17]; [18]; [19]; [20]; [21]) [22] name various operation modes based on the operation

type and the ownership of production and distribution (see Table 3).

To conclude, the REM model is designed as a simplistic theoretical tool for the analysis of internationalization at the enterprise level. Even if the REM model had been created particularly for the purposes of this research, it might also provide other case studies with an adequate framework to investigate internationalization (see Table 4).

\section{Methodology}

During the Soviet era, the primary goal of the Baltic corporations was to serve the needs of the whole Soviet economy i.e. the Baltic enterprises' production was large when compared to the size of their economy.

Table 2. Some Variables Influencing Environment Selection in the 1970s and the 1990s. Source [16]

\begin{tabular}{|c|c|c|}
\hline & In the 1970s & In the 1990s \\
\hline \begin{tabular}{l}
\multicolumn{1}{c}{$(\mathrm{A})$} \\
Resource \\
Seeking
\end{tabular} & $\begin{array}{l}\text { 1. Availability, price and quality of natural resources. } 2 \\
\text { Infrastructure to enable resources to be exploited, and } \\
\text { products arising from them to be exported, } \\
\text { 3. Government restrictions on FDI and /or on capital and } \\
\text { dividend remissions. } \\
\text { 4. Investment incentives, e.g., tax holidays. }\end{array}$ & $\begin{array}{l}\text { 1. As in the 1970s, but local opportunities for upgrading equality of resources and the } \\
\text { processing and transportation of their output is a more important locational incentive. } \\
\text { 2. Availability of local partners to jointly promote knowledge and/or capital-intensive } \\
\text { resource, exploitation. }\end{array}$ \\
\hline \begin{tabular}{l}
\multicolumn{1}{c}{$(\mathrm{B})$} \\
Market \\
Seeking
\end{tabular} & $\begin{array}{l}\text { 1. Mainly domestic, and occasionally (e.g., in Europe) } \\
\text { adjacent regional markets. } \\
\text { 2. Real wage costs; material costs. } \\
\text { 3. Transport costs; tariff and non-tariff trade barriers. } \\
\text { 4. As A3 above, but also (where relevant) privileged } \\
\text { access to import licenses. }\end{array}$ & $\begin{array}{l}\text { 1. Mostly large and growing domestic markets, and adjacent regional markets (e.g.. } \\
\text { NAFTA, EU etc.). } \\
\text { 2. Availability and price of skilled and professional labor. } \\
\text { 3. Presence and competitiveness of related firms, e.g., leading industrial suppliers. } \\
\text { 4. Quality of national and local infrastructure, and institutional competence. } \\
\text { 5. Less spatially related market distortions, but increased role of aggbmerative } \\
\text { spatial economies and local service support facilities. } \\
\text { 6. Macroeconomic and macro-organizational policies as pursued by host } \\
\text { governments. } \\
\text { 7. Increased need for presence close to users in knowledge-intensive sectors. } \\
\text { 8. Growing importance of promotional activities by regional or local development } \\
\text { agencies. }\end{array}$ \\
\hline $\begin{array}{l}\text { (C) } \\
\text { Efficiency } \\
\text { Seeking }\end{array}$ & $\begin{array}{l}\text { 1. Mainty production cost related (e.g., labor, materials, } \\
\text { machinery, etc.). } \\
\text { 2. Freedom to engage in trade in intermediate and final } \\
\text { products. } \\
\text { 3. Presence of agglomerative economies, e.g., export } \\
\text { processing zones. } \\
\text { 4. investment incentives, e.g., tax breaks, accelerated } \\
\text { depreciation, grants, subsidized land. }\end{array}$ & $\begin{array}{l}\text { 1. As in the } 1970 \text { s, but more emphasis placed on B2, 3, 4, } 5 \text { and } 7 \text { above, especially } \\
\text { for knowledge-intensive and integrated MNE activities, e.g., R\&D and some office } \\
\text { functions. } \\
\text { 2. Increased role of governments in removing obstacles to restructuring economic } \\
\text { activity, and facilitating the upgrading of human resources by appropriate educational } \\
\text { and trading programs. } \\
\text { 3. Availability of specialized spatial clusters, e.g., science and industrial parks, } \\
\text { service support systems etc.; and of specialized factor inputs. Opportunities for } \\
\text { initiatives by investing firms; an entrepreneurial environment, and one which } \\
\text { encourages competitiveness enhancing cooperation within and between firms. }\end{array}$ \\
\hline $\begin{array}{l}\text { (D) } \\
\text { Strategic } \\
\text { Asset } \\
\text { Seeking }\end{array}$ & $\begin{array}{l}\text { 1. Availability of knowledge-related assets and markets } \\
\text { necessary to protect or enhance } O \text { specific advantages } \\
\text { of investing firms - and at the right price. } \\
\text { 2. Institutional and other variables influencing ease or } \\
\text { difficulty at which such assets can be acquired by foreign } \\
\text { firms. }\end{array}$ & $\begin{array}{l}\text { 1. As in the 1970s, but growing geographical dispersion of knowledge-based assets, } \\
\text { and need of firms to harness such assets from foreign locations, makes this a more } \\
\text { important motive for FDI. } \\
\text { 2. The price and availability of "synergistic" assets to foreign investors. } \\
\text { 3. Opportunities offered (often by particular sub-national spatial units) for exchange of } \\
\text { localized tacit knowledge, ideas and interactive learning. } \\
\text { 4. Access to different cultures, institutions and systems; and different consumer } \\
\text { demands and preferences. }\end{array}$ \\
\hline
\end{tabular}


Table 3. Twelve Entry Modes and Their Variants Source [22]

\begin{tabular}{|c|c|c|c|}
\hline \multicolumn{2}{|c|}{ TYPE } & \multirow{2}{*}{$\begin{array}{l}\text { DESCRIPTION } \\
\text { Entrant owns foreign production } \\
\text { and distribution facilities. }\end{array}$} & VARIANT \\
\hline & Normal FDI & & $\begin{array}{l}\text { 1.1. Both facilities are greenfield. } \\
\text { 1.2. Both facilities are acquired. } \\
\text { 1.3. Production is greenfield and } \\
\text { distribution is acquired. } \\
\text { 1.4. Distribution is greenfield and } \\
\text { production is acquired. }\end{array}$ \\
\hline 2. & FDI in production & $\begin{array}{l}\text { Entrant owns foreign production but uses } \\
\text { independent distribution facilities. }\end{array}$ & $\begin{array}{l}\text { 2.1. Production is greenfield. } \\
\text { 2.2. Production is acquired. }\end{array}$ \\
\hline 3. & Subcontracting & $\begin{array}{l}\text { Entrant owns foreign distribution but uses } \\
\text { independent production facilities. }\end{array}$ & $\begin{array}{l}\text { 3.1. Distribution is greenfield. } \\
\text { 3.2. Distribution is acquired. }\end{array}$ \\
\hline 4. & FDI in distribution & Entrant exports to own distribution facility. & $\begin{array}{l}\text { 4.1. Distribution is greenfield. } \\
\text { 4.2. Distribution is acquired. }\end{array}$ \\
\hline 5. & Exporting/franchising & Entrant exports to independent facility. & \\
\hline 6. & Licensing & $\begin{array}{l}\text { Entrant transfers technology to independent } \\
\text { integrated firm. }\end{array}$ & \\
\hline 8. & $\mathrm{JV}$ in production & $\begin{array}{l}\text { Entrant jointly owns foreign production but } \\
\text { uses an independent distribution facility. }\end{array}$ & \\
\hline 9. & $\mathrm{JV}$ in distribution & $\begin{array}{l}\text { Entrant jointly owns foreign distribution but } \\
\text { subcontracts production to an independent facility. }\end{array}$ & \\
\hline 10. & JV exporting & Entrant exports to a jointly owned distribution facility. & \\
\hline 11. & FDI/JV combination & $\begin{array}{l}\text { Entrant owns foreign production and } \\
\text { jointly owns foreign distribution. }\end{array}$ & $\begin{array}{l}\text { 11.1. Production is greenfield. } \\
\text { 11.2. Production is acquired. }\end{array}$ \\
\hline 12. & JV/FDI combination & $\begin{array}{l}\text { Entrant owns foreign distribution and } \\
\text { jointly owns foreign production. }\end{array}$ & $\begin{array}{l}\text { 12.1. Production is greenfield. } \\
\text { 12.2. Production is acquired. }\end{array}$ \\
\hline
\end{tabular}

Table 4. The REM Model

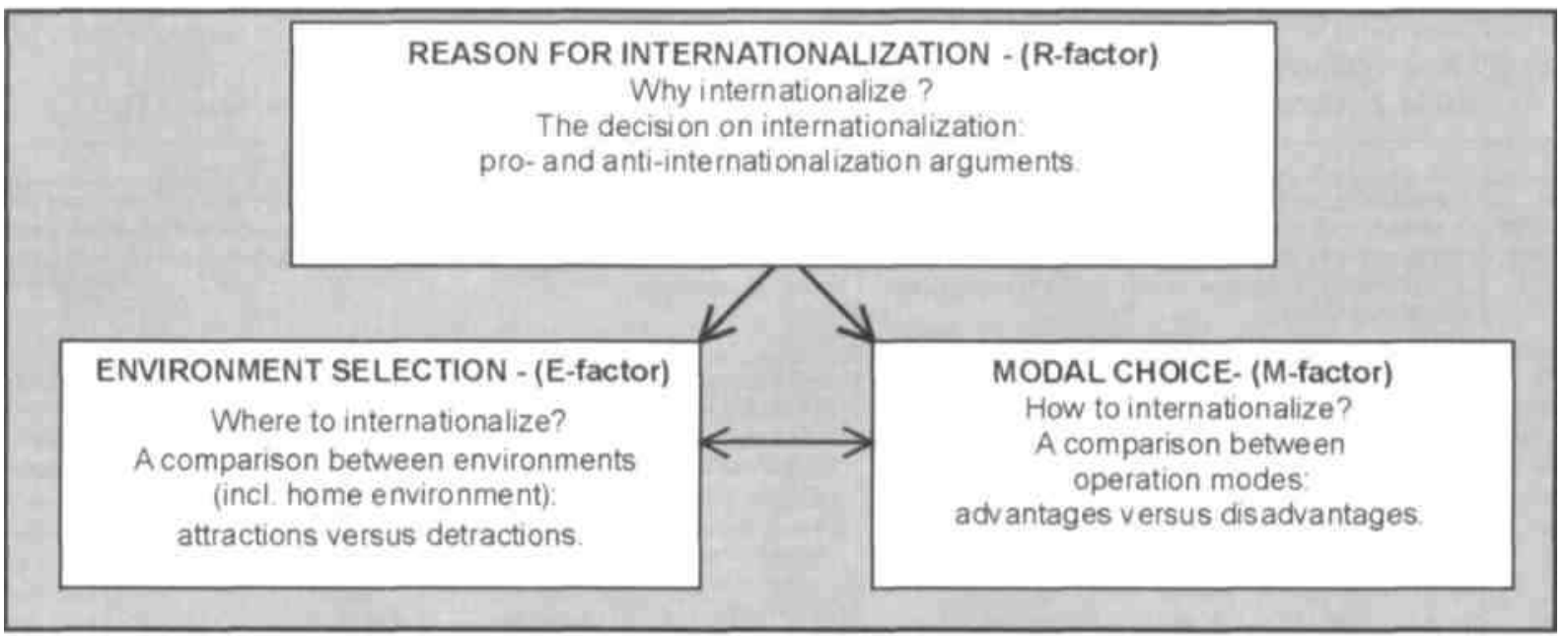

Due to the disintegration of the Soviet Union, the Baltic companies' home market diminished dramatically, and the Baltic firms were either forced to adjust their production to domestic demand or to find compensating markets abroad.

As no earlier empirical study has been conducted on the internationalization of Baltic corporations (at least

no such study was found), the authors decided to search for an answer to the following research questions:
* To what extent have the largest Baltic companies already moved their operations abroad?

* What are the main driving forces behind the internationalization (R-factor)?

* What are the main target environments of the internationalization (E-factor)?

* What are the main operation modes used (M-factor)?

Due to limited research funds, the researchers were forced to limit the sample size, and thus, they focused 
the study on the 100 largest companies in each Baltic State. These 300 were selected on the basis of their net turnover/sales.

The authors deliberately decided to focus the study on the largest corporations for three main reasons. First, should the researchers have aimed at random sampling among almost half a million registered business units in the Baltic States, the outcome of the study would most probably have been less successful, because a large proportion of the registered enterprises do not operate. This would inevitably have caused an enormous non-response. Secondly, smaller companies have usually less need, resources or skills for their internationalization. This would most probably have resulted in a great percentage of those answers indicating that the firm has not yet started its internationalization. Thirdly, the investigation was focused on the largest companies, due to their economic importance. The success of these companies' internationalization is crucial for the economic development of the Baltic States, since they form a significant part of the Baltic GDP and industrial production.

The questionnaire designed for the research is based on the REM model. In other words, the questionnaire deals with the reason, environment, and mode of the internationalization. The authors considered that the questionnaire should be linguistically as clear as possible, to avoid the possibility of misunderstanding. It was also decided that the questionnaire should not exceed two pages and it should not include too sensitive issues, such as exact performance indicators or ownership arrangements, since both a lengthy questionnaire and too sensitive questions would have reduced the Baltic managers' willingness to fill the questionnaire (see Appendix 1).

The above methodological decisions proved to be correct, since the response rate was rather satisfactory, over one-third, especially taking into consideration that the mail survey was conducted among the post-socialist companies, which arc usually reluctant to reveal any information to researchers (see [23]). In this context, it should be mentioned, that due to the researchers' persistent efforts, two reminders, the response rate then increased from some $20 \%$ to $38 \%$ (see Table 5).

The Estonian companies were more active in participating in the survey than the Latvian and the Lithuanian firms. Even if the Latvian and Lithuanian corporations were less enthusiastic to take part in the research, the response is not so much unbalanced by their lesser enthusiasm that the over- or under-representation of any country would distort the analysis on the internationalization of the largest Baltic corpora- tions. The participating companies also represent various business fields in each of the countries in question, so no distortion was resulted in this matter, either (see Appendix 2).

The analysis of the fulfilled questionnaires indicates that those questionnaires received by the researchers were rather accurately answered; though deficiencies could be detected from the questions concerning the geographical division of the exports. On the basis of the response analysis, it can be assumed that using English in the questionnaire did not result in an incorrect interpretation of the questions, and thus, the received answers are believed to be valid and credible. Most probably, the research language did not cause the non-response as much as managers' hectic timetables or a fear of the data getting into 'wrong' hands.

The questionnaires were sent for the first time on the 12th of January and the last questionnaire, which was included in the analysis was received two months later, on the 11th of March, 2001. Because the firms from transition economies expand their activities abroad at an ever-increasing speed, the empirical data will become outdated relatively fast, and therefore, it is extremely important to conduct follow-up studies frequently.

\section{Empirical Results}

\subsection{Exports of the Baltic Companies}

Almost two thirds of the respondents (64\%) indicated that their company has exports. The export frequency among the Latvian corporations was considerably lower, only one half of the studied Latvian companies have exports. When one remembers that the Latvian firms were more active in their activities abroad than the Estonian and Lithuanian ones, their lower export activity is a bit puzzling.

The companies that have exports were asked to indicate the share of the exports out of their total sales.

Table 5. The Response to the Survey

\begin{tabular}{|lc|}
\hline \multicolumn{2}{|c|}{ Response description } \\
\hline No reply & 179 \\
Replied that the company does not reveal information & 8 \\
Usable reply & $\mathbf{1 1 3 ( 3 8 \% )}$ \\
Total & 300 \\
\hline \multicolumn{2}{|c|}{ The division of usable reply by country } \\
\hline Estonia & $\mathbf{4 2} \%$ \\
Latvia & $27 \%$ \\
Lithuania & $\mathbf{3 1} \%$ \\
Total & $100 \%$ \\
\hline
\end{tabular}


The data reveals that over one-third of the companies have no exports, a fifth of the companies exports less than one-fifth, and for the rest, the exports compose $50 \%$ or more of the total sales (see Table 6).

Table 6. The Share of Exports of the Total Sales in the Baltic Companies ( $\mathrm{N}=113)$

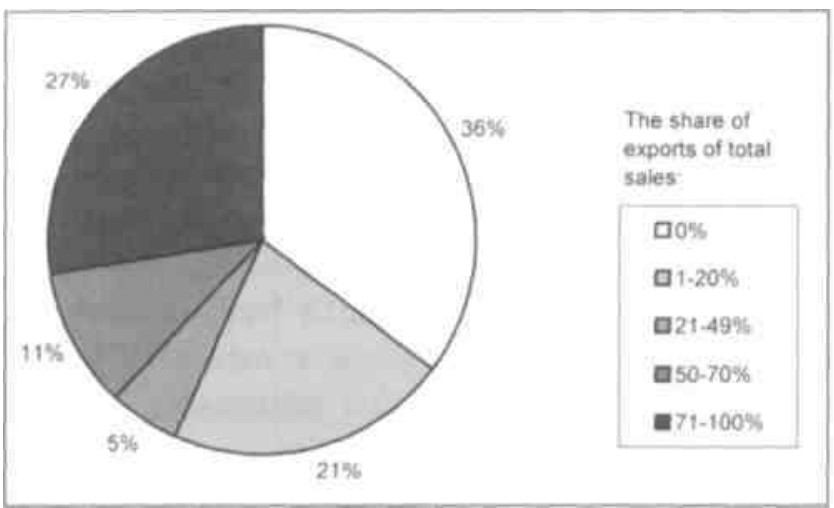

The EU and another Baltic State(s) are the most common destinations for the exports. Of those companies that have exports, more than two-thirds export to the EU or/and to another Baltic State(s). The EU is especially favored among the export-oriented companies i.e. if the proportion of the exports from the total sales is high, the company is likely to export to the EU. To put it differently, if a Baltic company exports to the $\mathrm{EU}$, it seldom has any other significant destinations for exports. Respectively, if a company exports elsewhere, the exports are divided between many countries (see Table 7).

Russia is the third most favored export destination, after the EU and another Baltic State(s). The share of Eastern Europe was not so high. In fact, the Baltic companies export more often to the USA than to Eastern Europe.

\subsection{The Baltic Corporations' Operations Abroad}

It is not exceptional to find a Baltic enterprise, which have already started its operations abroad. Some $42 \%$ of the studied companies have begun their operations in a foreign market (see Table 8).

The table above shows that operations abroad are more common among the Latvian corporations than the Lithuanian and Estonian ones. The empirical data cannot reveal any apparent explanation, why Latvian companies are more active in starting operations abroad than their Estonian and Lithuanian counterparts.
Table 7. The Division of the Baltic Companies' Exports to Another Baltic State and to the EU

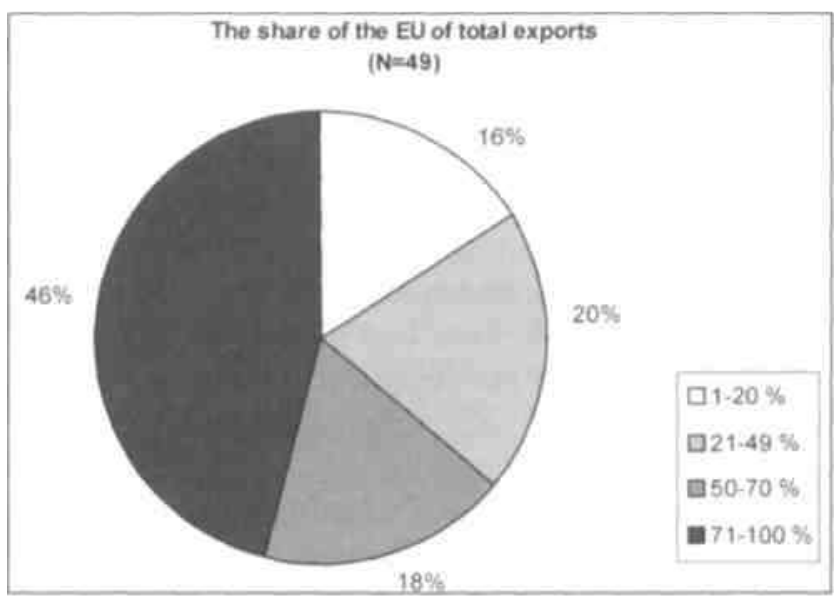

The share of another Baitic State of total exports $(\mathrm{N}=50)$

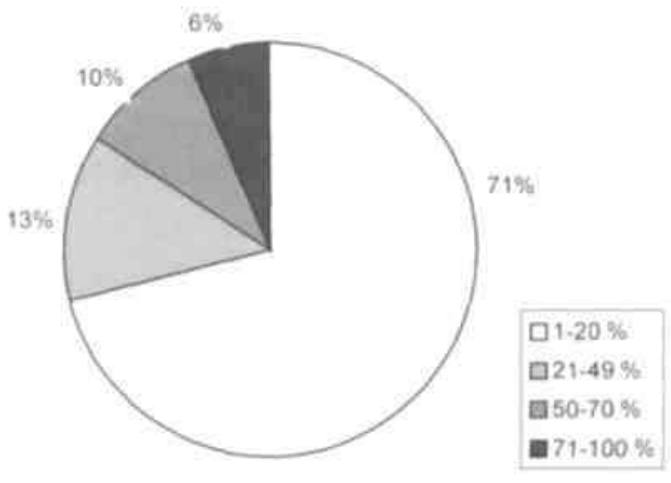

Table 8. The Studied Baltic Companies Abroad

\begin{tabular}{|c|c|c|c|}
\hline \multicolumn{2}{|c|}{} & \multicolumn{2}{c|}{$\begin{array}{l}\text { Does the company operate } \\
\text { abroad? }\end{array}$} \\
\cline { 3 - 4 } \multicolumn{2}{|c|}{} & No & Yes \\
\hline \multirow{3}{*}{ Country } & Estonia & $57 \%$ & $43 \%$ \\
\cline { 2 - 4 } & Latvia & $50 \%$ & $50 \%$ \\
\cline { 2 - 4 } & Lithuania & $65 \%$ & $35 \%$ \\
\hline Total & & $58 \%$ & $42 \%$ \\
\hline
\end{tabular}

The majority of the Baltic companies stated that driving force for their internationalization was getting a foothold in a larger economy. The option "internationalization is a necessity" was in second position. The aim of getting a better price was the third most frequently selected alternative. Surprisingly, "preparation for the EU accession" was selected by only $13 \%$ of those companies which have operations abroad. All in all, it can be concluded that the domestic factors pushing Baltic companies abroad seems to be behind the reasons for their internationalization rather than the attractions of foreign markets per se (see Table 9). 
Table 9. The Reasons for Baltic Companies to Operate Abroad ( $\mathrm{N}=48$ ). (As a company may have several reasons for operating abroad, the sum of percentages exceeds

$$
100 \% \text {.) }
$$

\begin{tabular}{|l|c|}
\hline \multicolumn{1}{|c|}{ Reason } & Frequency \\
\hline To get a foothold in a larger economy & $58 \%$ \\
Internationalization is a necessity & $54 \%$ \\
To get a better pnce & $44 \%$ \\
To secure the availability of raw materials or skilled & $19 \%$ \\
labor & $17 \%$ \\
Competition is not so hard abroad & $17 \%$ \\
More stable business environment & $13 \%$ \\
Foreign owner's influence & $13 \%$ \\
Domestic clients are already abroad & $13 \%$ \\
Preparation for the EU accession & $10 \%$ \\
To decrease transportation costs & $6 \%$ \\
To avoid/reduce custom duties or other tariffs & $6 \%$ \\
Production costs are lower & $4 \%$ \\
To reduce their tax burden & $0 \%$ \\
Investment incentives offered by host/home government & \\
\hline
\end{tabular}

Though the EU has an important role as a destination for the Baltic companies' exports, companies do not self-evidently seem to turn to the West in their operations. In fact, operations in other Baltic State(s) and in Russia arc more common than operations in the EU (see Table 10).

Table 10. The Operations of the Baltic Companies Abroad ( $\mathrm{N}=48$ ). (As a company may have operations in many regions, the sum exceeds $100 \%$.)

\begin{tabular}{|l|c|}
\hline \multicolumn{1}{|c|}{ Environment } & Frequency \\
\hline Another Baltic State(s) & $63 \%$ \\
Russia & $44 \%$ \\
TheEU & $40 \%$ \\
Other ex-Soviet republic(s) & $23 \%$ \\
Eastern Europe & $21 \%$ \\
The USA & $17 \%$ \\
Asia & $13 \%$ \\
Elsewhere & $6 \%$ \\
\hline
\end{tabular}

Starting operations in other Baltic State(s) is natural, as the Baltic States form a relatively familiar market place. Their geographical proximity can be another explanatory factor. The Estonian and Latvian companies, in particular, seemed to have chosen to expand their operations in another Baltic State, while the Lithuanian firms have penetrated into some other regions.

It is noteworthy to mention that also distant regions, like the United States and Asia, are represented among the environments where operations have been started. Latvian companies, in particular, have discovered these 'remote' environments.
If one analyzes the reasons for the internationalization and the environment selection together, an extremely interesting finding can be discovered. The EU is not regarded as "a larger economy", but Russia and the CIS are. In other words, Russia and the CIS are selected if the Baltic corporation's goal is to search for a larger market. The EU is chosen on a different basis.

The data clearly indicates that the largest Baltic companies do not prefer to start production abroad. Similarly, joint ventures are not a very widely-used operation mode. Instead, almost half of the companies with operations abroad indicated that they have their own representative offices (see Table 11).

Table 11. Baltic Companies' Operating Modes Abroad $(\mathrm{N}=48$ ). (As a company may use many operation modes simultaneously, the sum exceeds $100 \%$.)

\begin{tabular}{|l|c|}
\hline \multicolumn{1}{|c|}{ Mode } & Frequency \\
\hline Own representative office/s & $48 \%$ \\
Marketing co-operation with foreign firms & $40 \%$ \\
Own sales units & $35 \%$ \\
Subcontracting/icensing/franchising & $23 \%$ \\
Completely owned producton units & $19 \%$ \\
Joint venture with another firm & $17 \%$ \\
Equity ownership in a foreign company & $10 \%$ \\
Own investmentholding company abroad & $10 \%$ \\
\hline
\end{tabular}

27 out of 32 corporations indicated that they have employees abroad. However, not more than two firms stated that they have the majority of their staff abroad. 28 companies announced they have assets abroad, but not more than six companies have moved over $50 \%$ of their assets outside their country. Estonian companies have been more active than their counterparts in Latvia and Lithuania to shift their assets abroad (see Table 12).

As indicated already in Table 1, only one Baltic company reached the list of the 25 most transnational companies coming from Central and Eastern Europe. The empirical evidence of this study also indicates that several other transnational Baltic companies exist. The data also makes reference to the fact that the field of operation is not the main explanatory factor for moving assets and employees abroad, but several different fields of operations can be detected behind these Baltic companies.

\subsection{Future Operations Abroad}

Table 13 shows that only $28 \%$ of the companies studied expressed having plans to start operations abroad. The data does not reveal a significant difference bc- 
Table 12. The Transnationality Analysis of the Studied Baltic Corporations

\begin{tabular}{|c|c|c|c|c|c|}
\hline Country & Flek) & Assets abroad (\%) & Sales abroad (\%) & Employment abroad (\%) & Transnationality index \\
\hline Latvia & Shipping & 85 & 90 & 60 & 78 \\
\hline Latvia & Trade & 60 & 60 & 50 & 57 \\
\hline Latvia & Pharmaceuticals & 75 & 80 & 5 & 53 \\
\hline Estonia & Shipbuilding & 15 & 80 & 10 & 35 \\
\hline Estonia & Automobile equipment & 1 & 90 & 10 & 34 \\
\hline Lithuania & Construction & 10 & 60 & 30 & 33 \\
\hline Estonia & Beverages & 15 & 67 & 5 & 29 \\
\hline Estonia & Trade & 30 & 20 & 35 & 28 \\
\hline Estonia & Security services & 30 & 25 & 25 & 27 \\
\hline Lithuania & Textiles & 2 & 76 & 2 & 27 \\
\hline Estonia & Trade & 20 & 20 & 20 & 20 \\
\hline Estonia & Construction & 22 & 22 & 11 & 18 \\
\hline Estonia & Travel services & 15 & 15 & 20 & 17 \\
\hline Estonia & Textiles & 10 & 30 & 5 & 15 \\
\hline Estonia & Port services & 10 & 20 & 10 & 13 \\
\hline Latvia & Foodstuffs & 5 & 23 & 2 & 10 \\
\hline Lithuania & Stevedoring & 2 & 20 & 3 & 8 \\
\hline Estonia & Foodstuffs & 1 & 20 & 3.5 & 8 \\
\hline Latvia & Computers & 6 & 15 & 3 & 8 \\
\hline Lithuania & Construction & 1 & 15 & 5 & 7 \\
\hline Estonia & Transport & 90 & 75 & N/A & N/A \\
\hline Estonia & Trade & 75 & N/A & N/A & N/A \\
\hline Lithuania & Oil-petroleum products & 67 & N/A & N/A & $\mathrm{N} / \mathrm{A}$ \\
\hline Estonia & Shipping services & 40 & 80 & N/A & N/A \\
\hline Lithuania & Textiles & 30 & 30 & N/A & N/A \\
\hline Latvia & Oil products & 20 & N/A & 2 & N/A \\
\hline Latvia & Dairy & 10 & 20 & N/A & N/A \\
\hline Latvia & Transport & N/A & 70 & 2 & N/A \\
\hline Lithuania & Construction & N/A & N/A & 20 & N/A \\
\hline Estonia & Forestry & N/A & N/A & 2 & N/A \\
\hline Lithuania & Cereals & N/A & 28 & 1 & N/A \\
\hline Lithuania & Vehicles & N/A & 1.6 & 0.4 & N/A \\
\hline
\end{tabular}

tween the Baltic companies' interest in beginning operations abroad in the future. Moreover, the answers indicate that the company's existing operations abroad does not seem to reflect whether a company plans to start further operations abroad i.e. firms with no experience in foreign operations are planning to start operations abroad $(15 \%)$ as frequently as those enterprises with experience $(13 \%)$.

While eleven companies indicated that they have plans to expand their operations in another Baltic State, only seven companies mentioned the EU as the target environment. In fact, Russia was more popular than the EU. Nine companies planned to start their operations in the EU. Keeping in mind the small number of the response, the empirical evidence tentatively indicates that the largest companies in the Baltic States perceive

Table 13. The Companies' Intentions to Operate Abroad

\begin{tabular}{|c|c|c|c|c|}
\hline & \multicolumn{2}{|c|}{ Company already operates abroad } & \multirow[t]{2}{*}{ Total } \\
\hline & & No & Yes & \\
\hline \multirow{2}{*}{$\begin{array}{l}\text { Planning to start } \\
\text { operations abroad }\end{array}$} & Yes & $15 \%$ & $13 \%$ & $28 \%$ \\
\hline & No & $46 \%$ & $26 \%$ & $72 \%$ \\
\hline Total & & $61 \%$ & $39 \%$ & $100 \%$ \\
\hline
\end{tabular}

the EU as a trading partner rather than a destination for their expansion.

\section{Conclusion}

Over $60 \%$ of the studied enterprises expressed that they have exports. Also a relatively high percentage of the firms indicated that they have started operations abroad, some $40 \%$. These high percentages do not come as surprise, since the Baltic States are small markets, which automatically pushes most of the largest Baltic corporations abroad.

Some $60 \%$ of the companies indicated that a foothold in a larger economy was one reason to start operations abroad. The second most frequently given answer was "internationalization is a necessity to survive in future business", over 50\%. Thirdly, the Baltic corporations expand their activities in foreign markets to receive a better price for their commodity.

All these aforementioned responses could be easily anticipated, but it is very surprising that the preparation for EU accession did not rank higher among the 
Table 14. The Internationalization of the Baltic Companies in the REM Model

\section{R - REASON FOR INTERNATIONALIZATION: WHY INTERNATIONALIZE?}

10 main reasons behind the Baltic corporations' internationalization:

1) Small domestic market forces the Baltic companies abroad (small economy-related driving force).

2) Survival in future business requires internationalization (a global trend in business).

3) Baltic firms expect to receive a better price for their commodity abroad (relatively low buying power in the post-socialist countries).

4) Securing a resource supply (the Baltic States are relatively poor in natural resources).

5) Baltic companies are searching for less competitive markets, especially in other former Soviet republics (inter-enterprise competition seems to be fiercer in the Baltic States than in other ex-Soviet republics).

6) The Baltic firms are searching for more stable markets in the West (a goal to increase predictability in their enterprise development).

7) Foreign ownership in the company influences their internationalization decision (internal driving force).

8) Domestic clients have expanded their operations abroad (following the own client principle).

9) The preparation for EU accession (a need for Pan-European 'internationalization').

10) Logistical reasons have attracted Baltic companies abroad (a goal to improve efficiency).

\section{E - ENVIRONMENT SELECTION: WHERE TO INTERNATIONALIZE ?}

5 main environments, where Baltic firms have started their operations:

1) The Baltic market is the key foreign environment (a familiar and close foreign market).

2) Russia's potential attracts (earlier business relationships and experience).

3) The EU has attracted surprisingly few Baltic companies to start their operations there, though the EU is the main export direction (a fear of competition or EU regulations ?).

4) Other ex-Soviet republics (earlier experience and less-fierce competition).

5) Eastern Europe (Baltic products' price-quality ratio suit both East European demand and buying power).

\section{M - MODAL CHOICE: HOW TO INTERNATIONALIZE ?}

- Various marketing operations dominate (a goal to increase sales, while keeping financial investments low).

- Subcontracting, licensing, franchising (minimizing risks, while penetrating a foreign market).

- Joint venturing is a mode, which allows partners to join their resources and knowledge.

- Their own production unit abroad is still a relatively rarely used operation mode.

- Acquisition of a foreign company is still a rare option, mainly due to financial constraints.

\section{PECULARITIES CONCERNING THE BALTIC FIRMS' INTERNATIONALIZATION:}

- Despite the EU dominance in exports and the approaching EU membership of the Baltic States, surprisingly few Baltic firms have started their operations within the current EU.

- The ex-socialist bloc clearly dominates as an environment, where foreign operations have been started.

- The majority of the Baltic firms are not planning to start operations abroad in the near future. 
Table 15. Foreign Direct Investment Stock in the Baltic States by Investing Countries

\begin{tabular}{|c|c|c|c|c|c|c|c|c|}
\hline \multicolumn{3}{|c|}{ Estonia } & \multicolumn{3}{|c|}{ Latvia } & \multicolumn{3}{|c|}{ Lithuania } \\
\hline Investing country & $\begin{array}{c}\text { FDI stock in } \\
2001^{*} \text { (mn USD) }\end{array}$ & $\begin{array}{l}\text { \%Of } \\
\text { total }\end{array}$ & Investing country & $\begin{array}{c}\text { FDI stock in } \\
200 \Gamma^{*}(\text { mnUSD })\end{array}$ & $\begin{array}{l}\% \text { \% } \\
\text { total }\end{array}$ & Investing country & $\begin{array}{c}\text { FDI stock in } \\
2001^{* * *}(\mathrm{mn} \text { USD) }\end{array}$ & $\begin{array}{l}\text { \%of } \\
\text { total }\end{array}$ \\
\hline 1. Sweden & 1031.4 & 37.6 & 1. Denmark & 191.9 & 14.0 & 1. Denmark & 426.1 & 18.3 \\
\hline 2. Finland & 790.9 & 288 & 2. Germany & 174.4 & 12.7 & 2 Sweden & 404.5 & 17.3 \\
\hline 3. Netherlands & 156.5 & 5.7 & 3. Sweden & 139.8 & 10.2 & 3. USA & 229.4 & 9.8 \\
\hline 4. USA & 137.9 & 5.0 & 4. USA & 127.6 & 9.3 & 4. Germany & 172.3 & 7.4 \\
\hline 5. Denmark & 107.8 & 3.9 & 5. Russia & 99.8 & 7.3 & 5. UK & 155.9 & 6.7 \\
\hline 6. Norway & 83.1 & 3.0 & 6. UK & 91.1 & 6.6 & 6. Estonia & 149.3 & 6.4 \\
\hline 7. Germany & 83.0 & 3.0 & 7. Estonia & 83.2 & 6.1 & 7. Finland & 140.7 & 6.0 \\
\hline 8. UK & 71.4 & 2.6 & 8. Finland & 73.4 & 5.4 & 8. Switzerland & 113.0 & 4.8 \\
\hline 9. Liechtenstein & 41.7 & 1.5 & 9. Norway & 56.7 & 4.1 & 9. Norway & 99.3 & 4.3 \\
\hline 10. Russia & 39.1 & 1.4 & 10. Netherlands & 41.0 & 3.0 & 10. Luxembourg & 792 & 3.4 \\
\hline & & & & & & 16 Russia & 23.4 & 1.0 \\
\hline TOTAL & 2741.7 & 100.0 & TOTAL & 1371.0 & 100.0 & TOTAL & 2334.3 & 100.0 \\
\hline
\end{tabular}

$*$ As of 30.6.2001, currency converted using EEK 18.22:US\$1, *** As of 1.1.2001, currency converted using LVL0.607:US\$1, *** = As of 1.1.2001.Sources: Bank of Estonia (2001), [11], [10].

reasons for starting internationalization. The responses of the Baltic managers indicate that the approaching EU membership is not the driving force

for the Baltic corporations' internationalization, even though the EU is clearly the major export destination.

The Baltic corporations' management may think that they are able to maintain sales to the EU even without starting-up their own operations inside the current EU. In a way, maintaining production inside the Baltic States can be rational decision since it allows the Baltic corporations to take advantage of lower production costs while enjoying the benefits of the European Single market. On the other hand, EU membership may attract more EU and even non-EU companies to the Baltic States, and hence, increase competition inside the Baltics.

Consequently, increasing competition will force the Baltic companies to improve their effectiveness, either via increasing their size or by sharpening their focus. If the Baltic corporations do not manage to improve their competitiveness, we can witness an increase in bankruptcies, mergers and takeovers in the Baltic States in this decade (see Table 14).

The empirical evidence shows that the operations of the Baltic companies in foreign markets have concentrated on the cx-CMEA countries, especially in the former USSR. The explanation for focusing on the exCMEA market may stem from the fact that the Baltic commodities' price-quality ratio better fits these markets than those of the developed West. Also, their earlier business relations and experience in these markets may have offered a competitive advantage to the Bal- tic corporations, compared to their Western rivals.

The empirical evidence supports the presumption that most of the operations abroad are related to marketing, such as establishing their own representative office or their own sales unit in a foreign market. These sales increasing activities are a logical modal choice since they do not require heavy financial investment. It can be assumed that operational modes, which require more investment and risk taking will increase along with the improvement of the Baltic firms' financial position.

In closing, it can be argued that internationalization is a necessary condition, though not a sufficient condition by itself, for securing the Baltic corporations' survival in future business. Therefore, Baltic corporations must build strategic alliances between each other or some foreign companies to be able to cope with the competitive pressures arriving both from the EU and from the East, as it can be predicted that Russian companies will intensify their investment activities in the Baltic States in years to come.

Until now, Russian investments in the Baltics have remained relatively modest (see Table 15). In Latvia, Russia formed some $7 \%$ of the FDI stock in 2000. Both in Estonia and Lithuania Russian investments represented only some $1-2 \%$ of the FDI stock ([10]; [11]). However, it would not be a surprise if Russian companies would decide to use the Baltic States as a familiar foothold to the EU single market, and hence, would already decide to increase their investments in the Baltic States before the Baltic States receive their EU membership [24]. 


\section{References}

1. CIA (2001) www.odci.gov/cia/publications/factbook/ country/html

2. EIU (2001a) Country Profile 2001 Estonia, The Economist Intelligence Unit, London.

3. EIU (2001b) Country Profile 2001: Latvia, The Economist Intelligence Unit, London.

4. EIU (2001c) Country Profile 2001: Lithuania, The Economist Intelligence Unit, London.

5. EBRD (1999) Transition Report 1999, European Bank for Reconstruction and Development, London.

6. Statistics Estonia (2001) www.stat.ee

7. Latvian Development Agency (2001) www.lda.gov.lv

8. Lithuanian Development Agency (2001) www.lda.lt

9. EBRD (2000) Transition Report 2000, European Bank for Reconstruction and Development, London.

10. Statistics Lithuania (2001) Statistical Yearbook of Lithuania 2001.

11. Statistics Latvia (2001) Statistical Yearbook of Latvia.

12. UNCTAD (2001) World Investment Report 2001, United Nations, New York.

13.0hmae K. (1990) The Borderless World, Harper, New York.

14.Gerlinger J. M., Beamish P. W. \& da Costa R. (1989) Diversification Strategy and Internationalization: Implications for MNE Performance, Strategic Management Journal 10, p. 109-119.

15. Rugman Alan M. \& Verbeke Alain (1998) Multinational Enterprise and Public Policy, Journal of International Business Studies 29/1, p. 115-136.

16. Dunning John H. (1998) Location and the Multinational Enterprise: A Neglected Factor?, Journal of International Business Studies 29/1, p. 45-66.
17. Chi Tailan \& McGuire Donald J. (1996) Collaborative Ventures and Value of Learning: Integrating the Transaction Cost and Strategic Option Perspectives on the Choice of Market Entry Modes, Journal of International Business Studies 27/2, p. 285-308.

18.Erramilli M. Krishna (1996) Nationality and Subsidiary Ownership Patterns in Multinational Corporations, Journal of International Business Studies 27/2, p. 225-248.

19. Hagedoorn John \& Narula Rajneesh (1996) Choosing Organizational Modes of Strategic Technology Partnering: International and Sectoral Differences, Journal of International Business Studies 27/2, p. 265-284.

20.Tse David K., Pan Yigang \& Au Kevin Y (1997) How MNCs Choose Entry Modes and Form Alliances: The China Experience, Journal of International Business Studies 28/4, p. 779-806.

21. Contractor Farok J. \& Kundu Sumit K. (1998) Modal Choice in a World of Alliances: Analyzing Organizational Forms in the International Hotel Sector, Journal of International Business Studies 29/2, p. 325-357.

22. Buckley Peter J. \& Casson Mark C (1998) Analyzing Foreign Market Entry Strategies: Extending the Internationalization Approach, Journal of International Business Studies 29/3, p. 539-562.

23. Michailova Snejina \& Liuhto Kari (2000) Organisation and Management Research in Transition Economies: Towards Improved Research Methodologies, Journal of East-West Business 6/3.

24. Liuhto Kari \& Jumpponen Jari (2002) International Activities of Russian Corporations - Where Does Russian Business Expansion Lead?, Russian Economic Trends, agreed to be published. 
APPENDIX 1. The Questionnaire

1. Does your company have exports (mark appropriate alternative with $\mathrm{X})$ ?
( )Yes
( ) No - if no, move to question 4.

2. The share of exports of total sales?
( ) $1-5 \%$
( ) $6-10 \%$
( ) $11-20 \%$
( ) $21-30 \%$ ( ) $31-40 \%$
( ) $41-49 \%$
( ) $50-60 \%$ ( ) $61-70 \%$
( ) $71-80 \%$
( ) $81-90 \%$
( ) $91-99 \%$
( ) $100 \%$

3. What is the share of the following markets of your company's exports?

$\begin{array}{ll}\text { EU } & \text { - } \% \\ \text { Another Baltic State } & -\% \\ \text { Russia } & -\% \\ \text { Other ex-Soviet republic/s } & -\% \\ \text { Eastern Europe } & -\% \\ \text { USA } & -\% \\ \text { Asia } & \%\end{array}$

Other, what $\%$

4. Does your company operate abroad (not taking into account exports) ?

( )Yes ( ) No - if no, move to question 7.

5. Which operation mode/s is your company using abroad (many answers possible) ?

(

) Marketing co-operation with a foreign firm/s

) Own representative office/s

) Own sales unit/s

) Joint venture with another firm

) Completely owned production unit/s

) Equity ownership in a foreign company/ies

) Own investment / holding company abroad

( ) Subcontracting / licensing / franchising agreement with a foreign company

( )Other, what

\section{In which regions your company has started} business operations (not exports)?

$\begin{array}{lcc}\text { EU } & \text { ( )Yes } & \text { ( )No } \\ \text { Another Baltic State } & \text { ( )Yes } & \text { ( )No } \\ \text { Russia } & \text { ( )Yes } & \text { ( )No } \\ \text { Other ex-Soviet republic/s ( )Yes } & \text { ( )No } \\ \text { Eastern Europe } & \text { ( )Yes } & \text { ( )No } \\ \text { USA } & \text { ( )Yes } & \text { ( )No } \\ \text { Asia } & \text { ( )Yes } & \text { ( )No } \\ \text { Other, what } & & \text { ( ) Yes }\end{array}$

Employees Profits

$\%$

$\%$

8. What are the reasons why your company has started operations abroad ?

( ) To get a foothold in a larger economy

( ) To get a better price

( ) Production costs are lower abroad

( ) To decrease transportation costs

( ) To secure availability of raw materials or skilful labor

( ) To avoid / to reduce custom duties or other tariffs

( ) To reduce tax burden

( ) Due to investment incentives offered by host or home government

( ) Due to more stable business environment

( ) Due to better business infrastructure

( ) Domestic clients have started their operations abroad

( ) Influence of foreign owner in your company's management

( ) Competition is not so hard abroad as in the home market

( ) Preparation for the accession of your country in theEU

( ) Internationalization is a necessity to survive in the future business

( ) Other, what

9. Are you planning to start operations abroad (not exports) ?

( ) Yes, when

( ) No - if no, move to the end of the questionnaire.

10. In which regions you are planning to start operations (not exports) ?

$\begin{array}{lcl}\text { EU } & \text { ( )Yes } & \text { ( )No } \\ \text { Another Baltic State } & \text { ( )Yes } & \text { ( )No } \\ \text { Russia } & \text { ( )Yes } & \text { ( )No } \\ \text { Other ex-Soviet republic/s ( )Yes } & \text { ( )No } \\ \text { Eastern Europe } & \text { ( )Yes } & \text { ( )No } \\ \text { USA } & \text { ( )Yes } & \text { ( )No } \\ \text { Asia } & \text { ( )Yes } & \text { ( )No } \\ \text { Other, what } & & \text { ( )Yes }\end{array}$

Thank you for your valuable

contribution! If you

wish to receive the research report on the internationalization of the 300 largest Baltic companies, please write your company's address below or enclose your business card in the reply letter.

7. What is the share of the following activities of your company's performance?

\begin{tabular}{llll}
\multicolumn{2}{c}{ Home market } & \multicolumn{2}{c}{ Abroad } \\
Assets & $\%$ & & $\%$ \\
Sales & $\%$ & & $\%$
\end{tabular}


APPENDIX 2. The Sample ' EsTONIA

\begin{tabular}{|c|c|c|}
\hline Company & Field & $\begin{array}{l}\text { Net sales } \\
\text { MOO EEKY? }\end{array}$ \\
\hline Festi Fnergija AS & Energy & 3923722 \\
\hline Festi Telefon AS & Telecommunication & 2404577 \\
\hline Hansatec Grupp AS & Transport & 1825.772 \\
\hline Eundi Mobulicletion AS & Telecommunication & 1460597 \\
\hline Eesu Polevkuvi AS & Mining & 1455408 \\
\hline 6. Festi Raudtee As & Transport & 1401398 \\
\hline 7. Sylvester Grupp AS & Wood processing & 1070939 \\
\hline 8. Tallinna Kaubamaja AS & Trade & 996079 \\
\hline 9. Kreenholmi C.rupp & Textiles & 984846 \\
\hline 10. Pakterminal As & Transit & 978644 \\
\hline 11. ETK Hulgi AS & Trude & 878205 \\
\hline 12. Neste Fenti AS & Oil-petroleum made & 874918 \\
\hline I3. Tallinna Soojus AS & Energy & 822504 \\
\hline 14. Kaupmees \& Ko AS & Trade & 812140 \\
\hline 15. Tallinna Sadam AS & Port services & 8037.32 \\
\hline 16. Siockmann AS & Trade & 793.736 \\
\hline 17. Eevil Gatas AS & Encrgy & 7626.46 \\
\hline \multicolumn{3}{|c|}{ 18. Balti Iaesaremonditehase } \\
\hline As & Shipbuilding & 761264 \\
\hline 19. Merko Ehitus AS & Construction & 733657 \\
\hline 20 Eviontan AIr AS & Transportation & 720.981 \\
\hline 21 Saku Othuchare AS & Beserages & 215040 \\
\hline 22 LMVAS & Construction & 686735 \\
\hline 23 Bankind Ecul AS & Triakte & 6,52237 \\
\hline 24. Onake Eesti AS & Oil-petroleum trade & 646990 \\
\hline 25 Premum Oil AS & Oil-peiroleum irade & 627320 \\
\hline 26. EOS AS & Transit & 621627 \\
\hline 27. Eisti Statoil AS & Oil-petrofeum trade & 592466 \\
\hline 28. Fstline As & Transport & $5 \% 729$ \\
\hline 29 EE Girupp AS & Construction & 5961727 \\
\hline 30. Storat Enso Mets AS & Wood processing & 586865 \\
\hline 31. Fanaal AS & Building matterials & 582.39 .3 \\
\hline 32. NT Manne AS & Services for ships & 578321 \\
\hline 3.3. Enōli Kaubanduve AS & Oul-petroleum trade & $553.5,34$ \\
\hline 34. Viru Keemia grupp AS & Chemicals & 552.538 \\
\hline 35: Kakvere Lihakombmath AS & Fookstufis & 539535 \\
\hline 36. Festi Metallicksport As & Metal trade & 531159 \\
\hline 37. FKSM AS & Port services & 524326 \\
\hline 38. Norma AS & Automobile seat beits & $516+100$ \\
\hline 39. Eesti Post AS & Post services & 507602 \\
\hline 40. GSG AS & Oil-petroleum Irade & 507316 \\
\hline 41. ETK Maksumarkcti AS & Trade & 499084 \\
\hline 42. Siurn Petrolcum AS & Oil-petroleum trasle & 496.409 \\
\hline 4.3. Falck Baltics (ESS AS) & Security services & $4 \times 0547$ \\
\hline 44. Tallinna Kuimionenc AS & Food-tutfs & 454988 \\
\hline 45. Eesti Mereagentuur AS & Stevedoring & $4.38 \times 3.30$ \\
\hline 46. Jungent $O U$ & Trade & $430 \quad 151$ \\
\hline 47. Tallinna Vesi AS & Utilities & 426803 \\
\hline 48. S-Marten AS & Trade & 408116 \\
\hline 49 Elontcy Tallonn AS & Electrentes & 403663 \\
\hline 50. Kannila Profiil As & Building materials & 400150 \\
\hline 51: AIK Trans AS & Trainsit & $3907 / X\}^{7}$ \\
\hline 52. Tamro Festi & Pharmaceuticals & 388930 \\
\hline
\end{tabular}

\begin{tabular}{|c|c|c|}
\hline Company & 600 & $\begin{array}{l}\text { Net sales } \\
\text { o EEKr? }\end{array}$ \\
\hline 53. Fstravel as & Travel services & 388500 \\
\hline 54. Einll Coka Cola Joogid AS & Forodstufis & 382195 \\
\hline 55, JOT Eesti OU & Electronics & $3801+4$ \\
\hline \multicolumn{3}{|l|}{ 56. Honzon Trelluloosi ja } \\
\hline 57. Kunda Nordic Trement AS & Butding materials & 373967 \\
\hline 58 Tallinna Piamaficantuse AS & Dary & 366,748 \\
\hline 59. Maveke AS & Fondstufts & 366923 \\
\hline 60. Si Kaubabaasi & Trade & 350954 \\
\hline $61 \quad$ Kalev AS & Confectionery pondustur & $\sin 38511$ \\
\hline 62. ES Sadolin AS & Building materials & 332417 \\
\hline 63. Fania-Deslas & Trade & $329 \times 76$ \\
\hline 64. Toyota Baltic AS & Trade & 326277 \\
\hline 65. Repo Vabrihud AS & Wool processing & 325793 \\
\hline 66. Keske Festi AS & Trade & 325460 \\
\hline 67 Vehu Ecsu AS & Track & 323167 \\
\hline 68. Hiin Kalur AS & Foodstufrs & $31+721$ \\
\hline 69. HTM Sport Festi ()[] & Sport eyuipment & 409 213 \\
\hline 70 Siemens AS & Efiectronics & $30816 \times$ \\
\hline 71. Silmet Grupp AS & Chemicak & 305213 \\
\hline 72. Tallegg As & Foodstufls: & 303772 \\
\hline 73. Metsind AS & Timber products & 292247 \\
\hline 74, Silherauto is & Trade & 291018 \\
\hline 75. Baltika AS & Beverages & $2 \times 6926$ \\
\hline 76. Ericesun Ecsti AS & Trade & $28+362$ \\
\hline 77 Tech Data Eesu AS & Information lechnology & 282024 \\
\hline 78. Mets \& Puu AS & Forestry & $2 \times 1405$ \\
\hline 79. Marat AS & Textiles & 279964 \\
\hline 80. Rapla Daury & Darry & 279157 \\
\hline 81. АBBAS & Enctgetics & 274881 \\
\hline K2. Liviko AS & Alcotiol prinducts & 258813 \\
\hline 83. Rodiolinja Eest AS & Telecommunication & 253419 \\
\hline 84. Nitrofert AS & Chemicals & 253151 \\
\hline X5. ANB OHI Gineny, OC & $24 \times 4271$ & \\
\hline 86. Nordic Jetline AS & Travel services & $248+0 \%$ \\
\hline 87. AheStinek AS & Wholesule trade & $2432 \times 5$ \\
\hline 88. TVMKAS & Wood processing & 242551 \\
\hline 89. Forestex AS & Wood trade & 2.39161 \\
\hline \multicolumn{3}{|l|}{ 90. Valga Liha- ja } \\
\hline Konservitikntus AS & Foodviuffs & 236662 \\
\hline 91 Saksa Auto AS & Vetucle Irade & 235760 \\
\hline y2 Microlinh Arvutite AS & Information fecturalogy & 235370 \\
\hline 97 Tanu Olletchas AS & Beverages & 235132 \\
\hline 94 Shanska Ehituse AS & Construction & 232651 \\
\hline 95. Holmen Mets AS & Trade & 227005 \\
\hline 96. Tarmeko AS & $\begin{array}{l}\text { Furniture } \\
\text { manufacturing }\end{array}$ & $2262 \times 3$ \\
\hline 97. Baltex 2000 AS & Texules & 224963 \\
\hline 98. EVR Koehne AS & Construction & 22484.3 \\
\hline 99. Teede REV-2 AS & Construction & 224061 \\
\hline 106. Amisco AS & Shipping services & 220049 \\
\hline 101 Kommest Auto AS & Trade & 219648 \\
\hline 102. Sirdra Ecti AS & Papes products trade & 216447 \\
\hline
\end{tabular}

${ }^{1}$ The companies marked with bold returned a usable reply.

: In February 2001, one US dollar equaled 16.9 Estonian kroons (EEK).

${ }^{3}$ The companies marked in the brackets were not included in the research either because the researchers were not able to find the company's mail address. Also corporations operating in banking or in insurance business were dropped out of the survey. Moreover, the Latvian Privatization Agency was no approached. 


\begin{tabular}{|c|c|c|}
\hline Company & \multirow{2}{*}{$\begin{array}{l}\text { Field } \\
\text { Energy }\end{array}$} & $\begin{array}{l}\text { Net 'Turnover } \\
\text { (LVL million)' }\end{array}$ \\
\hline Latvenergo PVAS & & 167.56 \\
\hline Lattelkom SIA & Telecommunication & 129,30 \\
\hline Latvijas kugnieciba PVAS & Shipping & 111.79 \\
\hline Latvijas dzelzcels VAS & Transpont & 110,72 \\
\hline Turiba CS & Trade. catcring & 84.00 \\
\hline Latvijas Gaze AS & Energy & 83,08 \\
\hline $\begin{array}{l}\text { 7. Tatvijas Prikatizacijas } \\
\text { agentura VAS }\end{array}$ & Privatization & $70,04)$ \\
\hline Kurzemes degviela AS & Oil products & 67.77 \\
\hline $\begin{array}{l}\text { 9. Latvijas Mobilais telefons } \\
\text { SIA }\end{array}$ & Telecommunication & 64.60 \\
\hline 10. Rigas siltums AS & Heating & 63.95 \\
\hline II. Liepajas metalurgs AS & Metal industry & 56,64 \\
\hline 12. Latvija Statoil SIA & Oil products & 53,00 \\
\hline 13. Latvijas finieris AS & Woodworking & 50,10 \\
\hline 14. Ventpils nafta AS & Transit services & 45,86 \\
\hline 15. Ventpils tranzita serviss SIA & Oil transit & 44.92 \\
\hline $\begin{array}{l}\text { 16. Procter \& Gamble } \\
\text { Marketing Latvia SIA }\end{array}$ & Trade & 43,47 \\
\hline 17. Alianse-2 SIA & Trade, foodstuffs & 38.73 \\
\hline 18. Dinaz SIA KU & Oil products & 31.14 \\
\hline 19. (Karvijas unibanka AS & Finance & 30.98 \\
\hline 20. Nelss SIA & Woodworking, trade & 29,37 \\
\hline 21. (Parekss banka AS & Finance & $28.16)$ \\
\hline 22. Bravo SIA & Trade, beverages & 27.91 \\
\hline 23. Severstallat AS & Steel trade & 27.57 \\
\hline 24. Neste Latvija SIA & Oil products & 23,36 \\
\hline 25. Interpegro Latvija SIA KU & Trade & 23,30 \\
\hline 26. (Latijas Banka & Finance & $22,96)$ \\
\hline 27. Air Baltic Corporation AS & Transport & 22,74 \\
\hline 28. Rimi - Baltija SÍA & Retail trade & 22,20 \\
\hline 29. LUKoil Baltija R. SIA & Onl products & 21,92 \\
\hline 30. LatRos Trans SIA KU & Oil transit & 21,06 \\
\hline 31. Lex-USIA & Trade, foodstuffs & 20.86 \\
\hline 32. Lindeks AS & Wood trade & 20,01 \\
\hline 33. Greis SIA & Trade & 19,99 \\
\hline 34. Skonto buve SIA & Construction & 19.78 \\
\hline 35. Latvijas pasts VAS & Post service & 19,49 \\
\hline 36. Aldaris AS & Beverages & 19,35 \\
\hline 37. BMGS AS & Construction & 19,10 \\
\hline 38. Tamro SIA & Trade, medicines & 18,01 \\
\hline 39. Rigas udens PU & Municipal services & 17,70 \\
\hline 40. Linda SIA & Wood Irade & 17,65 \\
\hline 41. (Hansabanka AS & Finance & 17.45) \\
\hline 42. Ogre AS & Textiles & 17,25 \\
\hline 43. Venceb AS & Construction & 17,00 \\
\hline 44. Krasainic lejumi AS & Metal working & 16.86 \\
\hline 45. Skonto metals SIA & Metals & 16,49 \\
\hline $\begin{array}{l}\text { 46. Tramvaju un trolejbusu } \\
\text { parvalde PU }\end{array}$ & Transport & 16,38 \\
\hline 47. Eilko Riga SIA KU & Computers. trade & 16.03 \\
\hline 48. Mono SIA & Trade, insurance & 15,84 \\
\hline 49. (Balta AAS & Insurance & $(5,77)$ \\
\hline 50. Ventbunkers AS & Transit services & 15.77 \\
\hline 51. Rigas piena kombinats AS & Dairy & 15,33 \\
\hline 52. Riga kugu buvetava AS & Mechanical engineering & 15,19 \\
\hline 53. Viada SîA & Oil products & 15,10 \\
\hline 54. Baltkom GSM SIA KU & Telecommunications & 15,08 \\
\hline 55. Laima AS & Foodstuff's & 15,00 \\
\hline 56. Shell Latvia SIA & Oil products & 14,80 \\
\hline
\end{tabular}

\begin{tabular}{|c|c|c|}
\hline Company & \multirow{2}{*}{$\begin{array}{l}\text { Field } \\
\text { Trade }\end{array}$} & $\begin{array}{l}\text { Net Turnover } \\
\text { (LVL million)' }\end{array}$ \\
\hline 57. Unilever Baltic LLC SIA & & 14,62 \\
\hline 58 Latvijas Balzams AS & Beverages & 14.60 \\
\hline 59. Augstceltne SIA & Oil products & 14,51 \\
\hline 60. Preses apvieniba AS & Trade & 14,02 \\
\hline 61 Lauma AS & Textiles & 13,65 \\
\hline 62. Weeluk (Baltic) LId. SIA & Wood export & 13,64 \\
\hline 63. Ventspils ekspedicija SIA & Transit services & 13.60 \\
\hline 64. Cido partikas grupa SIA & Foodstuffs & 13,37 \\
\hline 65. Valmieras stikla skiedra AS & Chemical industry & 13,33 \\
\hline 66. (Larvijas krajhanka & Finance & $(3, I I)$ \\
\hline 67. Alkolats SIA & Beverages, trade & 13.00 \\
\hline 68. Karsten Latvian SIA & Trade & 12,82 \\
\hline 69. Rigas vini AS & Beverages & 12,80 \\
\hline 70. Lido nafta SIA & Oil products & 12.54 \\
\hline 71. Nelss TT & Trade & 12,17 \\
\hline 72. Silva SIA & Forestry & 12.06 \\
\hline 73. Unifex SIA & Trade & 11,87 \\
\hline 74. Skanska konstrukcija SIA & Construction & 11,80 \\
\hline 75 Latvijas nafta PVAS & Oil products & 11.78 \\
\hline 76. Dobeles dzimavnieks AS & Foodstuffs & 11,70 \\
\hline 77. Baltimar VT SIA & Oil products & 11.69 \\
\hline 78. Fortech SIA & Computers & 11,59 \\
\hline 79. SEL-IISIA & Beverages, trade & 11,59 \\
\hline 80. Hanzus maiznicas $\mathbf{A S}$ & Foodstuffis & 11,16 \\
\hline 81. Balffor SIA & Wood expon & 11,10 \\
\hline 82. Klangu kals SIA & Fuel trade & 11,08 \\
\hline 83. Rigas piensaimnieks $\mathrm{AS}$ & Duiry & 10,91 \\
\hline 84 Motors Latvia SIA & Cars. & 10.85 \\
\hline 85. CHS Riga SIA & Computers, trade & 10,80 \\
\hline 86. Kurekss SIA & Wood export & 10.73 \\
\hline 87. Cido logistika SIA & Foodstuffs, trade & 10,60 \\
\hline 88. Siemens SIA & Electronic equipment & 10,50 \\
\hline 89. Ventamonjaks AS & Transit services & 10.28 \\
\hline 90. (Austrumu alianse AAS & Insurance & $10.22)$ \\
\hline 91. Tolaram Fibers AS & Chemical industry & 9.88 \\
\hline 92. Grindeks AS & Pharmaceuticals & 9,85 \\
\hline 93. Diena AS & Publishing & 9.84 \\
\hline 94. Lattransrail SIA & Construction, transport & 9.80 \\
\hline 95. Oilands SIA & Fuel trade & 9,80 \\
\hline 96. Nokia Latvija SIA & Telecommunications & 9.72 \\
\hline $\begin{array}{l}\text { 97. Ventspils tirdzniecibas } \\
\text { osta AS }\end{array}$ & Stevedores & $\mathbf{9 , 7 0}$ \\
\hline 98. Rigas transporta fote AS & Shipping & 9,54 \\
\hline 99. Juraslicis AS & Fish industry & 9.50 \\
\hline 100. Nelda SLA & Trade & 9,50 \\
\hline 101. Rimako AS & Textiles & 9,50 \\
\hline 102. Ziemelu nafta SIA & Oil products & 9,50 \\
\hline 103. (Stalkers AS & Trude & $9,48)$ \\
\hline 104. Latvijas Gaisa satiksme & & \\
\hline VAS & Air navigation & 9.43 \\
\hline 105. Philips Latvija SIA & Trade & 9,40 \\
\hline 106. Bolderaja & Woodworking & 9,32 \\
\hline 107. Kalija parks AS & Pont services & 9.32 \\
\hline $\begin{array}{l}\text { 108. Baltijas transpona } \\
\text { apdrosinasana AAS }\end{array}$ & Insurance & 9,31 \\
\hline 109. Jelgavas cukurfabrika AS & Sugar producet & 9.20 \\
\hline 110. ISBV SIA & Construction & $9,(8)$ \\
\hline $\begin{array}{l}\text { III. Rezeknes piena konservu } \\
\text { kombinats AS }\end{array}$ & Dairy & 9,03 \\
\hline
\end{tabular}

${ }^{1}$ In February 2001, one US dollar equaled 0,62 Latvian lats (LVL). 
APPENDIX 2. Continued LITHUANIA

\begin{tabular}{|c|c|c|}
\hline Company & Field & \\
\hline $\begin{array}{l}\text { Mazeikiu nafta } \\
2.283923 .797\end{array}$ & \multicolumn{2}{|c|}{ Oil - petroleum products } \\
\hline Lictuvos Energija & Electric utilitics & 1468.362 .109 \\
\hline Lictuvos Telekomas & Telecom & 969493511 \\
\hline Lictusos Dujos & Natural gas utilities & $555,796,474$ \\
\hline L.ıetuvos Gelezinkeliaı & Transpon & 555.036 .257 \\
\hline L. Ifoxa & Chemicals & $494.171,030$ \\
\hline Achema & Chemicals & 339.954 .125 \\
\hline Ekranas & $\begin{array}{l}\text { Electrical } \\
\text { enginecring }\end{array}$ & 279.361 .166 \\
\hline $\begin{array}{l}\text { 9. Lictusos juru laivininkyste } \\
\text { (Lisico) }\end{array}$ & Shipping & 227.876 .164 \\
\hline 10. Rokiskio Suris & Dairy & 224.573 .000 \\
\hline II Kraft Foods Lictuva & Food & 214940933 \\
\hline 12. Lieluvos Avialinijos & Transpon & 196.718 .834 \\
\hline 13. Kauno Energija & Heating & 190.423 .314 \\
\hline 14. Alytaus Tekstile & Textile & 170.637 .187 \\
\hline 15. Lietuvos Kuras & $\begin{array}{l}\text { Oil-petroleum } \\
\text { products }\end{array}$ & 164145681 \\
\hline 16. Snaige & $\begin{array}{l}\text { Electrical } \\
\text { chginecring }\end{array}$ & 149903.872 \\
\hline 17. Piemo Zvaigzdes & Dairy & 147098.796 \\
\hline 18 Birzu Akcine Pieno & & \\
\hline Bendrove & Dairy & $145.811,210$ \\
\hline 19. Zemaitijos Pienas & Dairy & $138,682.501$ \\
\hline 20 Dirbtinis Pluostas & Chemicals & $121,059.952$ \\
\hline 21. Akmenes Cementas & Building muterials & 112.559 .709 \\
\hline 22 Whenos Tnkotazas & Clothing & 109000.973 \\
\hline 23 Kauno Tiltai & Construction & 106.210619 \\
\hline 24 Klaipedos Nafta & Shipbuilding & $105,044,716$ \\
\hline 25 Klaipedos Maistas & $\begin{array}{l}\text { Oil-petroleum } \\
\text { products }\end{array}$ & 102.128 .317 \\
\hline $\begin{array}{l}\text { 26. Klaipedos Juru Kroviniu } \\
\text { Kompanija }\end{array}$ & Stevedoring & 98.318 .852 \\
\hline 27. Kalnapilis & Brewery & 96.789 .184 \\
\hline 28. Kausta & Construction & 96.191 .725 \\
\hline 29 Vilmaus Duonat & $\begin{array}{l}\text { Confectionery \& } \\
\text { bread }\end{array}$ & 95.779 .952 \\
\hline 30. Alkesta & Construction & 94.627 .691 \\
\hline 31. Klaipedos Enetgija & Heating & 92.372773 \\
\hline 32. Klaipedos Mediena & Wood products & 91.013 .546 \\
\hline 33. Panevezio Keliai & Construction & 87.793 .625 \\
\hline 34. Panevezio Silumos Tinklai & Heating & 85.781 .631 \\
\hline 35. Baltik Vairas & Vehicles & 85.543 .158 \\
\hline 36. Baltijos I,aivu Statykla & Shiphuilding & 83.609 .478 \\
\hline 37. Marijampolex Pieno & & \\
\hline Konservai & Dairy & 81.336 .825 \\
\hline 38. Vilniaus Vingis & $\begin{array}{l}\text { Electrical } \\
\text { engineering }\end{array}$ & 81.225 .034 \\
\hline 39. Alita & Drinks & 79.095 .636 \\
\hline 40. Alytaus Silumos Tinklai & Heating & 78.794 .470 \\
\hline 41. Drobe & Textiles & 76.211 .074 \\
\hline 42 Limas & Textiles & 76.112 .350 \\
\hline 43. Anyksciu Vynas & Drinks & $75,550.468$ \\
\hline 44. Stumbras & Drinks & 74.315 .800 \\
\hline 45. Svyturys & Brewery & 73.714 .249 \\
\hline 46. Pinevezio Statybas Trestus & Construction & 72.743 .822 \\
\hline 47. Panevezio Pienas & Dairy & 72.107 .309 \\
\hline 48. Kretingos Grudai & Cereals & 72.089 .326 \\
\hline 49. Mesa & Meat products & 70.956 .604 \\
\hline $\begin{array}{l}\text { 50. Klaipedos Transporto } \\
\text { Laivynas }\end{array}$ & Shipping & 67.924 .971 \\
\hline
\end{tabular}

\begin{tabular}{|c|c|c|}
\hline Company & Field & $\begin{array}{l}\text { Sales } \\
\text { (LTL.) }\end{array}$ \\
\hline 51. Ventus-Nafta & $\begin{array}{l}\text { Oil - petroleum } \\
\text { products }\end{array}$ & 66.633 .657 \\
\hline 52. Vilniaus Paukstynas & Meat products & 65.722 .547 \\
\hline 53. Kauno Grudai & Cereals & 65.274 .339 \\
\hline 54. Lytagra & Trade & 62.286 .712 \\
\hline 55. Vievio Paukstynas & Meat products & 61.690 .456 \\
\hline 56. Viti & Construction & 59391.886 \\
\hline 57. Utenos Pienas & Dairy & 57.551 .366 \\
\hline 58. Klaipedos Pienas & Dairy & 57.056 .903 \\
\hline 59. Siauliu Energija & Heating & 55.715 .994 \\
\hline 60. Gngiskes & Paper and printing & 55.032 .095 \\
\hline 61. Montuotojas & Construction & 53707.841 \\
\hline 62. Hidrostatyba & Construction & 52.531 .905 \\
\hline 63. Siauliu Plentas & Construction & $52,208,124$ \\
\hline \multirow[t]{2}{*}{ 64. Alná } & Computer & \\
\hline & technologies & 50.439 .330 \\
\hline 65. Apranga & Trade & 50.140 .484 \\
\hline 66. Medienos Plausas & Paper and printing & $49.090 \times 74$ \\
\hline 67. Plasta & Plastics & 46.334 .624 \\
\hline 68 Klanpedos Baldat & Furniture & 46.259 .300 \\
\hline 69. Vilniaus Pefgale & $\begin{array}{l}\text { Confectionery and } \\
\text { bread }\end{array}$ & 43.654 .170 \\
\hline 70. Krekenaves Agrofirma & Meat products & 43.438 .295 \\
\hline 71. Malsena & Cereaix & 43.212 .918 \\
\hline 72. Sisuliu Stumbras & $\begin{array}{l}\text { Leather, leather } \\
\text { products }\end{array}$ & 42.436 .382 \\
\hline 73. Kaisiadoriu Paukstynas & Meat products & 40.888 .938 \\
\hline \multicolumn{2}{|l|}{ 74. Vilniaus Mesos } & 40.825 .482 \\
\hline 75. Dvarcioniu Keramika & Building materials & 40.609 .237 \\
\hline 76. Klaipedos Duona & $\begin{array}{l}\text { Confectionery and } \\
\text { food }\end{array}$ & 38.554060 \\
\hline 77. Levuo & Trade & 37.451 .682 \\
\hline 78. Siauliu Pienas & Dairy & 36.314 .344 \\
\hline 79. Lietuves Tara & Packaging & 35.726 .233 \\
\hline 80. Vernitas & Chemicals & 34.722 .023 \\
\hline 81. Kauno Pienas & Dairy & 34.168 .133 \\
\hline 82. Nemunas & Building materials & 33.952173 \\
\hline 83. Ragutis & Brewery & 32.841 .357 \\
\hline 84 Vilniaus Tauras & Brewery & 32.667 .879 \\
\hline 85. Metalu Komercija & Trade & 32.320 .756 \\
\hline \multicolumn{3}{|l|}{ 86. Vilniaus Baldu } \\
\hline 87. Audejas & Textiles & 31.759 .833 \\
\hline 88 Liteksas & Textiles & 31.551 .686 \\
\hline 89. Skailies & $\begin{array}{l}\text { Electrical } \\
\text { enginecring }\end{array}$ & 30758276 \\
\hline 90. Kauno Ketaus Liejykla & Building materials & 30.080 .704 \\
\hline 91 Alicjus & Oil production & 29722,948 \\
\hline 92 Silutes haldai & Fumiture & 29.432 .643 \\
\hline 93. Vilntaus Degtine & Drinks & $29,394.465$ \\
\hline 94. Ekinsta & Construction & 29.054 .622 \\
\hline 95. Kuro Aparatura & $\begin{array}{l}\text { Electrical } \\
\text { engincering }\end{array}$ & $28.356,018$ \\
\hline 96. Kelmes Pienine & Dairy & 28.129 .653 \\
\hline 97. Satrija & Clothing & 28.124 .632 \\
\hline 98. Siulas & Textiles & 27.910 .378 \\
\hline 99. Kedainiu grudai & Cereals & 26.62 .957 \\
\hline 100. Nawjogi ruta & $\begin{array}{l}\text { Confectionery } \\
\text { and bread }\end{array}$ & 25.971 .625 \\
\hline
\end{tabular}

${ }^{1}$ In January 2001, one US dollar equaled 4,00 Lithuanian litas (LTL). 